Review

\title{
Nanotechnology as an Alternative to Reduce the Spread of COVID-19
}

\author{
Roberto Vazquez-Munoz *(i) and Jose L. Lopez-Ribot \\ Department of Biology and The South Texas Center for Emerging Infectious Diseases, The University of Texas at \\ San Antonio. One UTSA Circle, San Antonio, TX 78249, USA; jose.lopezribot@utsa.edu \\ * Correspondence: roberto.vazquezmunoz@utsa.edu
}

Received: 23 June 2020; Accepted: 24 July 2020; Published: 27 July 2020

check for updates

\begin{abstract}
The current emerging COVID-19 pandemic has caused a global impact on every major aspect of our societies. It is known that SARS-Cov-2 can endure harsh environmental conditions for up to $72 \mathrm{~h}$, which may contribute to its rapid spread. Therefore, effective containment strategies, such as sanitizing, are critical. Nanotechnology can represent an alternative to reduce the COVID-19 spread, particularly in critical areas, such as healthcare facilities and public places. Nanotechnology-based products are effective at inhibiting different pathogens, including viruses, regardless of their drug-resistant profile, biological structure, or physiology. Although there are several approved nanotechnology-based antiviral products, this work aims to highlight the use of nanomaterials as sanitizers for the prevention of the spread of mainly SARS-Cov-2. It has been widely demonstrated that nanomaterials are an alternative for sanitizing surfaces to inactivate the virus. Also, antimicrobial nanomaterials can reduce the risk of secondary microbial infections on COVID-19 patients, as they inhibit the bacteria and fungi that can contaminate healthcare-related facilities. Finally, cost-effective, easy-to-synthesize antiviral nanomaterials could reduce the burden of the COVID-19 on challenging environments and in developing countries.
\end{abstract}

Keywords: COVID-19; nanotechnology; nanomaterials; antiviral; sanitizers; nanomedicine; infectious diseases

\section{Introduction}

Other than a natural disaster of cataclysmic proportions, or an all-out man-made nuclear war, infectious diseases pose the only global threat to human life on Earth. Infectious diseases have plagued humanity and represented the major cause of morbidity and mortality through the millennia, and in the process shaped human evolution. They still constitute the leading cause of premature death in the developing world. However, our modern society has become extremely complacent about the threat posed by infectious diseases, mostly due to the availability and increased access to hygiene and sanitization techniques, vaccines, and antibiotics.

Despite this unjustified level of complacency and the false sense of security, epidemiological experts and sentinel organizations around the world have provided ample warning signs, often ignored, of our global vulnerability against infectious diseases and their broad and borderless impact. Microorganisms do not need a passport and do not understand artificial geopolitical boundaries. This is further aggravated by globalization and climate change. In particular, the newest epidemics caused by a virus such as SARS, MERS, Ebola, and H1N1 since the beginning of the century have raised the awareness of the major threat that viral diseases still pose to humanity as a whole. However, these preoccupations were often short-lived and fast forgotten once the resulting epidemics were seemingly under control, which left us completely unprepared despite our conviction and anticipation that it was only a matter of time for the next epidemic or pandemic to come. Sure enough, we did not have to wait 
too much longer, and as of early 2020, humanity is confronting a pandemic in severe acute respiratory syndrome coronavirus 2 (SARS-CoV-2), which causes coronavirus disease, abbreviated as COVID-19.

\section{The SARS-CoV-2 Virus and the Current COVID-19 Pandemic}

The SARS-CoV-2 is a large, enveloped, positive-stranded RNA virus, with a nucleocapsid, with a similar structure to the SARS-CoV-1; and a diameter size range from 80 to $140 \mathrm{~nm}$ [1]. This zoonotic coronavirus has become a major cause of emerging respiratory disease and has rapidly spread around the globe, affecting billions of people, and triggering unexpected changes in the healthcare system, global economy, and interactions in societies worldwide.

So far, as of 23th July, there are over 14.6 million confirmed cases with COVID-19 worldwide, with an estimated death toll of over 607,000 people [2]. The costs related to this communicable disease are expected to be in the trillions of dollars globally, but the real cost cannot be estimated [3]. Implementing strategies to reduce its spread requires the participation of the whole society, as well as the development of innovative ways of social, work, and health policies. Several measures have been implemented to control COVID-19, from campaigns aimed at improving personal hygiene practices to community approaches such as social distancing and quarantines. Among the suggested public health activities to address this pandemic are (1) efficient stay-at-home implementation, (2) fast SARS-CoV-2 testing, and (3) efficient health care response. The last point considers protecting the health care professionals by providing tools to prevent nosocomial infections, from making appropriate personal protective equipment (PPE) available to ensuring sanitizing procedures.

Proper sanitizing measures are critical. A recent study revealed that SARS-CoV-2 can be detected on plastic and stainless-steel surfaces up to $72 \mathrm{~h}$, whereas on copper, no viable SARS-CoV-2 was measured after $4 \mathrm{~h}$ of application [4]. The inactivation of the virus by copper is not surprising, as it is known that transition metals can inactivate viral particles [5]. Thus, nanotechnology may provide an alternative for sanitizing surfaces, via antimicrobial and antiviral nanomaterials.

\section{The State-of-the-Art of Antiviral Nanomaterials: From Research to the Clinic}

\subsection{Nanomaterial Definition}

There are different definitions of the nanomaterial concept. In general, nanomaterials can be described as single-structures-free or in a composite-with a size within the nanometric range, usually less than $100 \mathrm{~nm}$ in at least one of their three dimensions. Within the nanometric range-the nanoscale-the physicochemical properties of materials display significant changes that contrast their counterparts at larger scales, as the quantum effects determine their new properties [6]. There is an increasing interest in nanomaterials, precisely due to their novel or improved physicochemical properties such as endurance, chemical reactivity, biocompatibility, conductivity, or reduced toxicity [7]. The chemical composition of nanomaterials can be organic or inorganic, and they can be found as single structures, composites, embedded in a matrix, etc. Nowadays, nanomaterials are found in a wide range of existing products, such as in electronics, health and fitness, paints and other surface coatings, food, and clothing, among many others [8-10]. Moreover, medicine is among the areas with a growing interest in the use of nanotechnology.

\subsection{Use in Nanomedicine}

Nanomaterials are widely used in different healthcare-related applications, such as sanitizers, diagnosis, imaging tools, wound dressing, wearable devices, anticancer therapies, pharmaceuticals, drug delivery, vaccines, diagnosis techniques, and implants, among others [11-13]. Nanomaterials have been researched for developing antiviral and antimicrobial drugs, as they display properties for combatting multiple pathogenic microorganisms [14-20]. The global consumption for healthcare-related nanotechnology is expected to be over 50 tons, just for silver nanoparticles, in 2020 [21]. 
Multiple nanomaterials can display antiviral activity. The chemical composition of these nanomaterials can be either organic or inorganic (metal-based); their typical shape is spheroid or polyandric (aspect ratio close to 1) with a usual size range from 1 to $50 \mathrm{~nm}$, and their active formulation is often as free particles in suspension. Antiviral nanomaterials are typically smaller than most viral particles, such as the SARS-Cov-2 viral particle, which has an average size of $120 \mathrm{~nm}$ [1] (Figure 1). Therefore, nanomaterials can interact with the whole viral particle or with the surface proteins and other structural components, leading to the inactivation of viruses. The characteristics of antiviral nanomaterials, their potential mechanisms of action, the ongoing preclinical/clinical research, and the currently approved products for consumer use are discussed below.
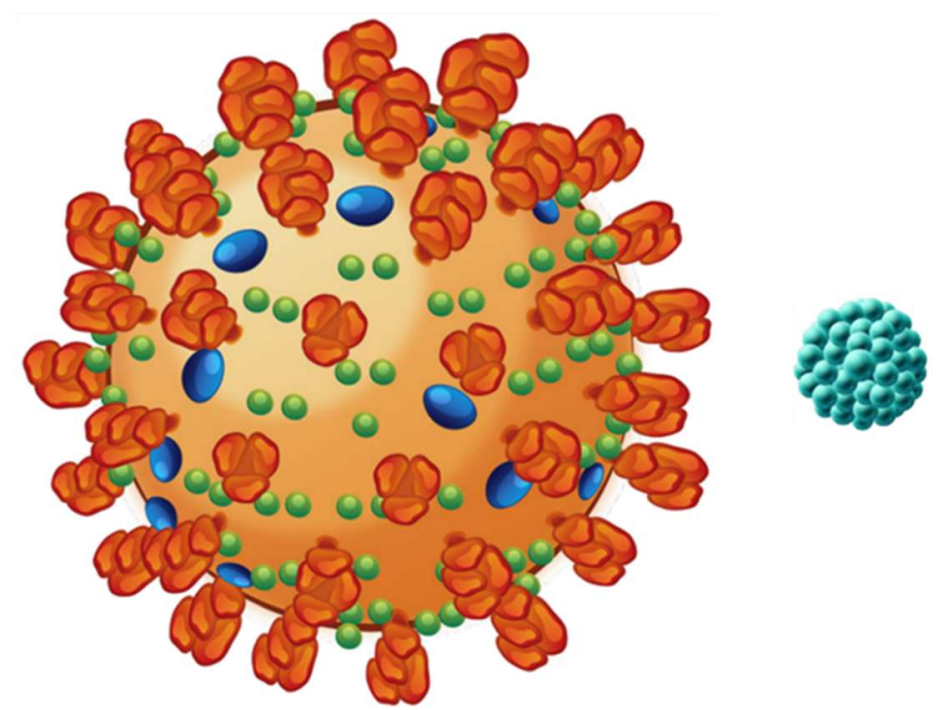

SARS-Cov-2: $120 \mathrm{~nm}$

AgNPs: $\sim 20 \mathrm{~nm}$

Figure 1. Size comparison between the average sizes of the SARS-Cov-2 coronavirus and a single silver nanoparticle (AgNPs). Both structures are at a proportional size.

\subsection{Preclinical Studies, In Vitro and In Vivo}

The antiviral activity of nanomaterials against multiple viral families has been studied in a wide diversity of reports (Table 1). Studies in vitro show that silver nanoparticles (AgNPs) inactivate different types of viruses, such as HIV-1 [22], monkeypox virus [23], hepatitis B [24], Tacaribe virus [25], and the Rift Valley fever virus [26]. Also, AgNPs display activity against influenza viruses like H3N2 [27] and H1N1 [28]. Current literature suggests that nanomaterials may also effectively inactivate the SARS-Cov-2 virus particles, as nanomaterials have been used for inhibiting other viruses from the Coronaviridae family [29]. Other nanomaterials also display antiviral activity against viruses that cause respiratory syndromes. Titanium oxide nanoparticles inhibit the H9N2 [30], carbon fullerene lipidosomes inactivate H1N1 [31], and a peptide-nanoparticle complex is capable of inactivating the influenza A virus [32]. Regarding other viruses, ivermectin-nanoparticles complexes can inactivate the Zika virus [33]. Therefore, nanomaterials can inactivate a wide variety of viruses, regardless of the viral structure and strain [34].

Moreover, several studies report the effectivity of nanomaterials for reducing viral replication, in vivo against viruses from multiple families (Table 2). In murine models, different nanomaterials are effective to inhibit the respiratory syncytial virus [35]; HIV [36], influenza virus [37], herpes simplex virus, human papillomavirus, dengue and lentivirus [38]. Additionally, antiviral nanomaterials display antiviral activity in other in vivo models; such as the canine distemper virus in dogs [39], the Newcastle disease virus in chicken [40], and the white spot syndrome virus in shrimp [41], among others. 
Table 1. A non-exhaustive list of examples of antiviral nanomaterials that inactivate different types of viruses, in preclinical assays in vitro.

\begin{tabular}{|c|c|c|c|c|c|}
\hline \multicolumn{4}{|c|}{ Antiviral Nanomaterial } & \multirow{2}{*}{ Virus } & \multirow{2}{*}{ Refs } \\
\hline Type/Composition & Shape & $\operatorname{Size}^{1}(\mathrm{~nm})$ & Coating & & \\
\hline \multirow{8}{*}{ AgNPs } & Spheroid & 2.08 & BSA & HIV-1 & [22] \\
\hline & Spheroid & $25,55,80$ & chitosan & Monkeypox & [23] \\
\hline & $\mathrm{N} / \mathrm{A}$ & 10,50 & N/A & Hepatitis & [24] \\
\hline & Spheroid & 10,25 & Uncoated \& Polysaccharide & Tacaribe & [25] \\
\hline & Spheroid & 35 & PVP & RVFV & {$[26]$} \\
\hline & Spheroid & 9.5 & Organic & H3N2 & [27] \\
\hline & Spheroid & $3.5,12.9$ & Chitosan & H1N1 & [28] \\
\hline & Spheroid & $5-25$ & Graphene oxide & Coronavirus & [29] \\
\hline $\mathrm{TiO}_{2} \mathrm{NPs}$ & Poly-shaped & 52.9 & N/A & H9N2 & [30] \\
\hline Carbon fullerene ${ }^{2}$ & N/A & N/A & $\mathrm{N} / \mathrm{A}$ & H1N1 & [31] \\
\hline Peptide-NPs ${ }^{3}$ & Dendritic & $2.4 \& 29.8$ & N/A & Influenza A & [32] \\
\hline Ivermectin-NPs ${ }^{3}$ & Spheroid & $60-140$ & IVM & Zika & [33] \\
\hline
\end{tabular}

${ }^{1}$ Average size. For the metallic nanoparticles, the size corresponds to their metallic core. ${ }^{2}$ Lipidosome complex. ${ }^{3}$ Hybrid complexes.

Table 2. A non-exhaustive list of examples of antiviral nanomaterials under preclinical assays in vivo.

\begin{tabular}{|c|c|c|c|c|}
\hline \multicolumn{2}{|r|}{ In Vivo Assay } & \multicolumn{2}{|r|}{ Antiviral Nanomaterial } & \multirow{2}{*}{ Refs } \\
\hline Model & Virus $^{1}$ & Type $^{2}$ & Traits & \\
\hline \multirow{6}{*}{ Murine } & RSV & AgNPs & $10 \mathrm{~nm}$ spheres, PVP coated & [35] \\
\hline & & PLGA NPs & $66 \mathrm{~nm}$ spheroids, 3-pot $=-10.96 \mathrm{mV}$ & [36] \\
\hline & HIV & I-tsNPs & $100 \mathrm{~nm}$ liposome spheroids, $3-$ pot $=-9.2 \mathrm{mV}$ & [42] \\
\hline & & Maraviroc-SDN & Multiple NPs: Size $650-850 \mathrm{~nm}$. & [43] \\
\hline & Influenza & Nano-Emulsion & $223-228 \mathrm{~nm}$ & [37] \\
\hline & HSV, RSV, HPV, DV, LV & HSPG-NPs & $<7 \mathrm{~nm}$, gold core, MES- or MUS-coated & {$[38]$} \\
\hline Dogs & CDV & $\mathrm{AgNPs}$ & $35 \mathrm{~nm}$, spheroids, PVP-coated & [39] \\
\hline Chicken & NDV & PR-NPs & $<80$ nm spherical & [40] \\
\hline Shrimp & WSSV & chitosan NPs & $160 \mathrm{~nm}$ & [41] \\
\hline
\end{tabular}

${ }^{1}$ RSV = respiratory syncytial Virus, HIV = human immunodeficiency virus, HSV = herpes simplex virus, HPV = human papillomavirus, $\mathrm{DV}=$ dengue, $\mathrm{LV}=$ lentivirus, $\mathrm{CDV}=$ canine distemper virus, $\mathrm{NDV}=$ Newcastle disease virus; WSSV = white spot syndrome virus. ${ }^{2}$ PLGA (poly[lactic-co-glycolic acid]) NPs; HSPG (heparan sulfate proteoglycans)-mimicking NPs; I-tsNPs= anti-CCR5 siRNA/LFA-1 I-tsNPs; PR-NPs= Polyrhodanine nanoparticles.

\subsection{Mechanisms of Action of Antiviral Nanomaterials}

Preclinical trials have shown how virus-nanoparticle interactions lead to direct or indirect antiviral activity. Nanomaterials with indirect activity do not inhibit the viruses by themselves; instead, they improve the activity of the antiviral treatments, and are used for transport [44], stability [45], and enhanced bioavailability [46], among others. Moreover, nanomaterials can also induce an immune response for generating short or long-term immunity [47]. In contrast, nanomaterials with direct activity act as the active compound, because they inactivate the viruses by themselves, usually by altering the viral structure or its genetic material.

Back in 2005, Lara et al., showed that AgNPs interact with the receptors from HIV, inhibiting its infectivity [48]. They suggested that AgNPs bind to the gp120 glycoprotein knobs, preventing the virus from binding to cells, as observed in their in vivo results. Also, Morris et al., suggested recently that AgNPs may be attaching to the surface glycoproteins of the virus [35]; which prevents the fusion process by reducing its ability to attach to the cells. Additionally, Cagno et al., showed that gold and iron oxide nanoparticles - coated with organic ligands-disrupt the ultrastructure of multiple viruses [38], breaking the viral particle, leading to virucidal inhibition of enveloped and naked viruses. Moreover, Kim et al., demonstrated that nanomaterials can silence viral genes, as they observed that in vivo administration of anti-CCR5 siRNA/LFA-1 I-tsNPs exclusively silenced genes in leukocyte for 
around 10 days, preventing the HIV infection [42]. In a recent review, Cojocaru et al., described the potential mechanisms that allow nanomaterials to inactivate both DNA and RNA viruses [49]. Among the main mechanisms are the viral DNA/RNA synthesis inhibition; viral protein synthesis inhibition; and inhibitors of the entry, fusion, or integration of viruses into the cell. The general mechanisms that nanomaterials display against viruses are exemplified in Figure 2.

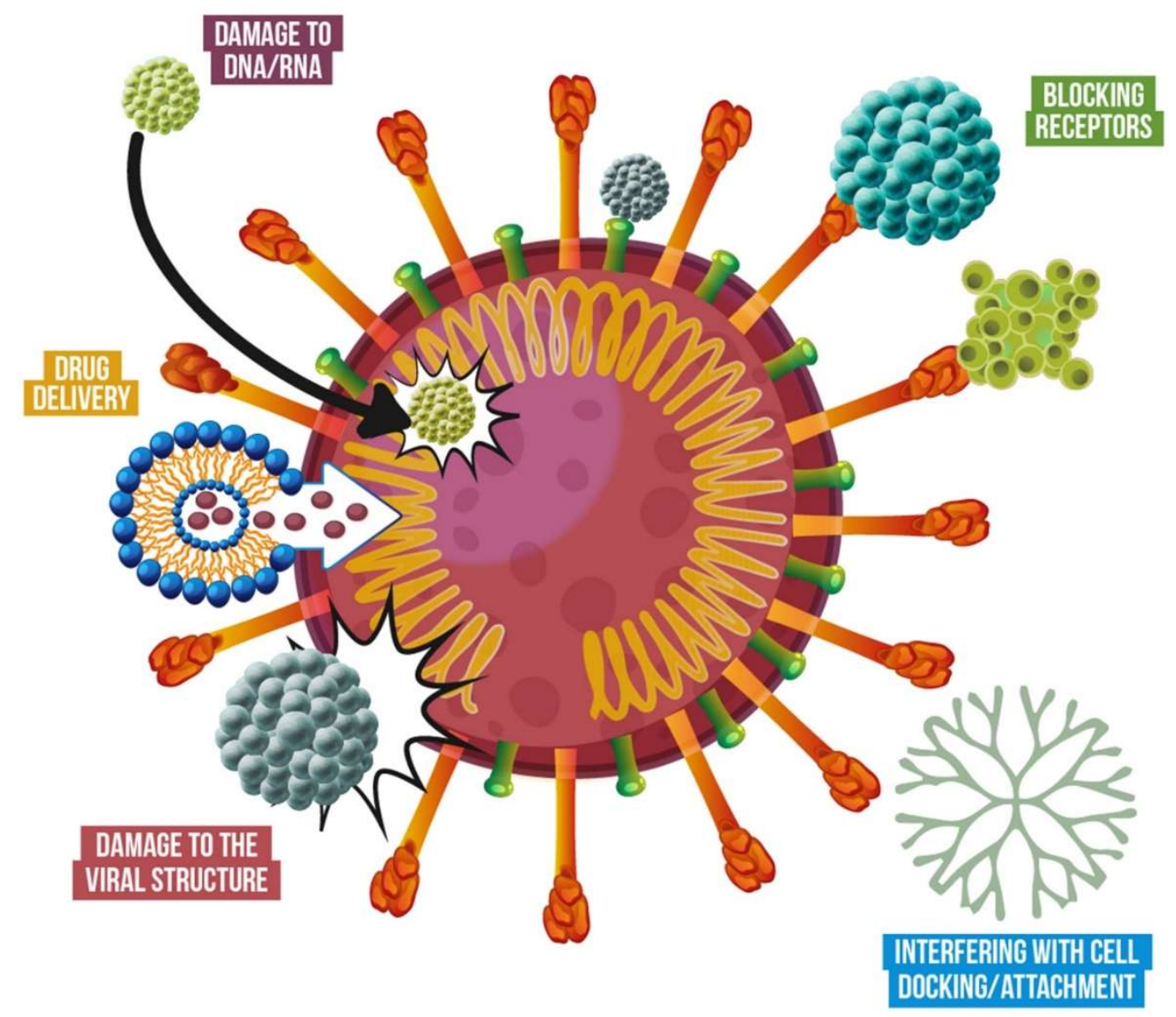

Figure 2. Proposed antiviral mechanisms that nanoparticles use to deactivate viruses.

Moreover, nanomaterials display other properties of clinical interest, such as enhanced chemical reactivity and biocompatibility, controlled drug release, and customizable target specificity [50,51], and may display reduced toxicity when compared to the non-nanostructured materials.

\subsection{Clinical Studies and Products in the Market}

Nowadays, multiple antiviral nanomedicines are still under clinical research, whereas others have been approved and are currently commercially available for use. Some recent reviews show the current stage of development of antiviral nanomedicines, from ongoing preclinical and clinical trials to those that are currently approved. Lembo et al., review how nanotechnology-based formulations improve the activity of antiviral drugs, describing the advantages provided by different nanomaterials [52]; whereas Sato et al., provide an insight of the status of several therapeutics anti-HBV undergoing clinical trials in phases 1 and 2 [47]; finally, Singh et al., present an overview of the research of nanomaterials, from preclinical research to clinical assays and commercialization, for the treatment of viral infections [53]. Some examples of FDA-approved, nanotechnology-based products are Inflexal V( , a virosomal anti-influenza vaccine, [44], and Pegasys $($, a pegylated IFN alpha 2a anti-Hepatitis (HBV and HVC) [54]. 


\section{Current Nanotechnology Applications that Can Be Used to Combat COVID-19}

As mentioned earlier, nanomaterials are currently used in multiple commercially available products, including cosmetics and healthcare. A detailed, updated list of products can be consulted at the Nanowerk databases [9]. The wide range of physical and chemical properties of nanomaterials provides numerous advantages to combat the SARS-Cov-2; from reducing its spread to future treatments. When antiviral nanomaterials are fixed in support, their stability and reactivity are increased, as well as the surface area of the support. Usually, nanomaterials are adsorbed by textiles [55] and polymers [56] for diverse applications, such as personal protective equipment (PPE), medical textiles, packaging, and filters. Nanomaterials in suspensions can be used for sanitizing, coatings, and therapeutic applications. Finally, multiple nanomaterials can be used for nanocarriers, diagnosis, and detection. Some of the current applications that can be used to prevent and treat the COVID-19 are described below and summarized in Figure 3.

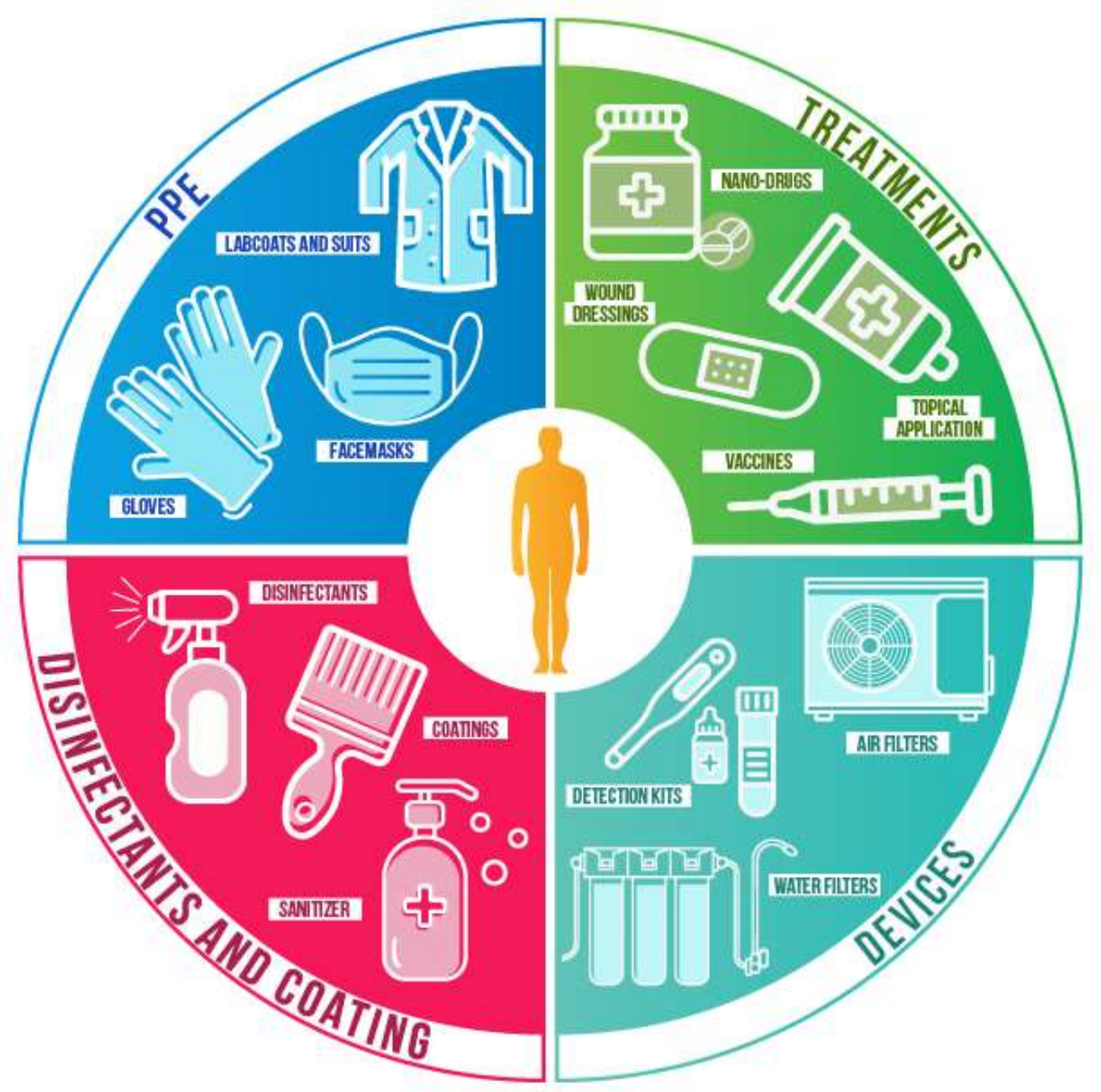

Figure 3. Representative uses of nanotechnology to combat viruses and other pathogens.

\subsection{Personal Protective Equipment (PPE)}

The application of nanomaterials-embedded textiles has been intensely researched, as they improve the physicochemical properties of textiles, such as fire-retardant, self-cleaning, antimicrobial, and UV-protection, among others [57,58]. Fibers embedded with metallic nanoparticles, such as copper and silver nanoparticles, display antimicrobial and antiviral properties [11,59]. Mao recently reviewed the use of nanotechnology for protective clothing-including PPE such as lab coats, aprons, and facemasks-as nanomaterials provide novel traits to the fabrics [60]. Nowadays, the use of 
nanoparticles in textiles has been increasing rapidly, with a current global consumption of around 35 tons just for silver nanoparticles [21]. Moreover, wearable smart textiles and electronics for sensing have been explored, particularly for health-related applications, as described by Libertino et al., as the early detection of pathogens is of particular interest [61]. Jayathilaka et al., suggest that wearables and textiles may be also used for drug delivery [62].

\subsection{Surface Coatings}

Nanomaterials-based coatings are currently used for several applications, and different products are now available, particularly from metallic elements such as silver, bismuth, copper, or titanium $[11,58,63,64]$. Also, nanostructured surfaces can physically reduce the attachment of pathogens [65] and even disrupt the structure of the pathogens due to the nanoscale topography organization [66]. Nanomaterials can be embedded in paints or coatings for medical instrumentation, walls, and other highly-touched surfaces, such as doorknobs, handrails, etc. for reducing the presence and viability of viruses and other pathogens. A recent review by Rai et al., describes multiple nanocoatings and their potential use in public places for reducing the presence of pathogens [67].

\subsection{Disinfectants and Sanitizing Procedures}

Disinfectants with silver salts are currently used [68], as silver is deemed safe for sanitizing purposes [69]. In hospitals and other healthcare-related facilities, sanitizing with nanotechnology-based products could decrease the viral presence on highly-touched surfaces and maintain them virus-free for longer, including the SARS-Cov-2 virus. Metallic nanoparticles may be a viable option, as the viability of the SARS-Cov-2 virus is reduced on a metallic (copper) surface [4].

\subsection{Other Current and Potential Applications}

Among other uses, nanomaterials can be used to improve the function of air filters in healthcare facilities or in other places that use recirculated air. Nanotechnology-improved devices can reduce the spread of viral particles, such as air filters [70-72] and for the removal of pathogens and viruses from water [73]. Also, the use of nanotechnology for producing wound dressings has been thoroughly explored [51,74,75], due to their ability to protect against infections and increase the healing speed rate. Future applications may include the development of improved detection kits, as it has been one of the major needs for the current strategies to contain and follow the virus spread. In a recent review, Hameed et al., describe the role of nanotechnology for emerging detection against pathogens [76]. Besides detection, there have been recent advances for nanotechnology-based smart packaging to prevent pathogens [77]. Although the reviews from Hameed et al., and Zhong et al., focus on food-related applications, these can be used in the clinical sector.

\section{A Silent Risk: The Microbial Secondary Infections}

The current COVID-19 pandemic has raised several health concerns beyond the disease itself, such as secondary infections, which has been an underestimated risk. Secondary infections may appear during or after treatment of the COVID-19, due to the burden on health caused by the virus. Patients infected with the novel strain of coronavirus frequently show microbial dysbiosis and a decrease of probiotic bacteria [78]. Also, it is not uncommon for patients with COVID-19 to suffer from complications of acute organ injury and secondary infection [79], which may be of microbial origin. Recently, Rawson et al., reviewed the current literature regarding microbial co-infections in patients with different coronaviruses; although the co-infection rate is low $(8 \%)$, they still pose a threat for COVID-19 patients [80].

A major risk associated with microbial infections is drug-resistance, which leads to failures in the treatments of the diseases. Currently, several health institutions worldwide point out that multidrug-resistant pathogens represent an urgent threat, as they cause thousands of deaths and their cost is incalculable. The CDC, in its latest Antibiotic Resistance Threats in the United States, lists 
current clinically microbial pathogens and describes the challenges associated with drug resistance [81]. Moreover, an additional threat is the formation of microbial biofilms (layers of microbial cells protected by an extracellular matrix), as they allow the microbial pathogens to survive sanitizing procedures harsh conditions. Biofilms allow microbial pathogens to have a constant presence in health-related facilities. Among the alternatives to combat pathogens, antimicrobial nanomaterials (nanoantibiotics) have been rising as a viable option.

Nanoantibiotics display a broad range antimicrobial activity against bacteria [82,83], protozoa [84,85], and fungi [86-89]. Metallic nanoparticles have been extensively studied, as metals have intrinsic antimicrobial properties [90] and they display antimicrobial activity regardless of the drug-susceptibly profile of microorganisms $[15,86]$. Additionally, nanomaterials may enhance the potency of current antimicrobial drugs; Vazquez-Munoz et al. recently described a potential mode of action between AgNPs and antibiotics that lead to synergistic effects [91]. Moreover, nanomaterials can reduce the microbial biofilms leading to a reduced risk of secondary microbial infections $[87,88,92]$. In Table 3 are listed examples of antimicrobial nanomaterials, with their properties and applications.

Table 3. Examples of types of nanoantibiotics with current and expected antimicrobial applications.

\begin{tabular}{|c|c|c|c|c|}
\hline \multicolumn{2}{|c|}{ Nanomaterials } & \multicolumn{2}{|c|}{ Common Antimicrobial Applications } & \multirow{2}{*}{ Refs } \\
\hline Type & Relevant Traits * & Pathogens & Uses ** & \\
\hline Silver & $\begin{array}{l}\text { High activity } \\
\text { Synergistic effects } \\
\text { Functional coating }\end{array}$ & $\begin{array}{l}\text { Bacteria, Fungi, } \\
\text { Protists }\end{array}$ & $\begin{array}{l}\text { Textiles, Coating, Cosmetics, } \\
\text { Sanitizers, Treatments }\end{array}$ & {$[14,93]$} \\
\hline Gold & $\begin{array}{l}\text { Binding with antibiotics } \\
\text { Low toxicity } \\
\text { Functional coating }\end{array}$ & Bacteria & $\begin{array}{l}\text { Treatments, Detection, Textiles, } \\
\text { Wearables }\end{array}$ & [94] \\
\hline Titanium & $\begin{array}{l}\text { Light-activated } \\
\text { Biocompatible } \\
\text { High stability }\end{array}$ & Bacteria, Fungi & Coating, Dentistry & [95] \\
\hline Copper & Stability & Bacteria, Fungi & Coating & [96] \\
\hline Lipid-based & $\begin{array}{l}\text { Non-toxic } \\
\text { Biocompatible }\end{array}$ & $\begin{array}{l}\text { Bacteria, Fungi, } \\
\text { Protists }\end{array}$ & Drug delivery, Cosmetics & {$[54,97,98]$} \\
\hline Chitosan-based & $\begin{array}{l}\text { Non-toxic } \\
\text { Support for metals }\end{array}$ & Bacteria, Fungi & Drug delivery, Textiles & {$[97,99]$} \\
\hline
\end{tabular}

* Distinctive traits are mentioned. These nanomaterials usually display an aspect ratio close to 1 (polyhedral or spheroids) with a size range within 5-50 $\mathrm{nm}$. They can be coated to add new properties. ** Current and intended uses.

An additional advantage is that there are a plethora of methods for synthesizing nanomaterials [100]; some methods can be easily reproduced in non-specialized facilities under unfavorable environments [101], therefore they could be produced for sanitizing in rural areas, mobile medical units, or in medical posts for the military on the field.

\section{Perspectives}

What should be expected in the near future? Although more research is needed, antiviral nanomaterials represent an alternative to reduce the spread of COVID-19, as they have been effective against other viruses. Based on the current knowledge, nanomaterials may be used in the present or the short-term for preventing the spread of the SARS-Cov-2 virus using antiviral sanitizers, nanotechnology-upgraded materials for PPE and medical instrumentation, and nanotechnology-enhanced fabrics for facemasks for general use. Particularly, nanotechnology-based sanitizers also display potent and broad antiviral and antimicrobial activity, therefore they can improve safety in healthcare-related facilities and public spaces, particularly in developing countries. 
Regarding upcoming applications, nanotechnology can be used for detection kits, vaccines, and treatments. Currently, the therapeutic use of antiviral nanotechnology-based drugs has proven to be effective and it will be expanded in the future as more research becomes available. Also, nanomaterials display a broad range of activity and they may enhance the antimicrobial potency of some drugs, therefore they can be used for preventing or treating secondary infections, particularly those with multidrug-resistant profiles.

Finally, protocols that favor facile, rapid, cost-effective syntheses of antimicrobial and antiviral nanomaterials produce potent nanomaterials that could reduce the spread of viruses and microorganisms. Affordable nanotechnology may benefit anti-COVID-19 sanitizing procedures in developing countries, where access to advanced materials is limited. Also, easy-to-synthesize nanomaterials may be used under non-favorable conditions, such as medical mobile-units, rural health care facilities, and highly transited public spaces.

Author Contributions: Both authors equally contributed to the conceptualization, writing-original draft preparation, and writing-review \& editing. All authors have read and agreed to the published version of the manuscript.

Funding: R.V.-M. acknowledges support from a postdoctoral fellowship from the Mexican Council of Science and Technology (CONACYT). J.L.L.-R. acknowledges support from the Margaret Batts Tobin Foundation. The authors would like to thank the graphic designer Salma Carballo for designing the images.

Conflicts of Interest: The authors declare no conflict of interest.

\section{References}

1. Cascella, M.; Rajnik, M.; Cuomo, A.; Dulebohn, S.C.; Di Napoli, R. Features, Evaluation and Treatment Coronavirus (COVID-19); StatPearls Publishing: Petersburg, FL, USA, 2020.

2. Coronavirus Resource Center COVID-19 Map. Available online: https://coronavirus.jhu.edu/map.html (accessed on 8 June 2020).

3. Orlik, T.; Rush, J.; Cousin, M.; Hong, J. Coronavirus Could Cost the Global Economy \$2.7 Trillion. Here's How. Available online: https:/www.bloomberg.com/graphics/2020-coronavirus-pandemic-global-economic-risk/ (accessed on 8 April 2020).

4. van Doremalen, N.; Bushmaker, T.; Morris, D.H.; Holbrook, M.G.; Gamble, A.; Williamson, B.N.; Tamin, A.; Harcourt, J.L.; Thornburg, N.J.; Gerber, S.I.; et al. Aerosol and Surface Stability of SARS-CoV-2 as Compared with SARS-CoV-1. N. Engl. J. Med. 2020, 382, 1564-1567. [CrossRef] [PubMed]

5. Nieto-Juarez, J.I.; Pierzchła, K.; Sienkiewicz, A.; Kohn, T. Inactivation of MS2 coliphage in Fenton and Fenton-like systems: Role of transition metals, hydrogen peroxide and sunlight. Environ. Sci. Technol. 2010, 44, 3351-3356. [CrossRef] [PubMed]

6. National Nanotechnology Initiative What's So Special about the Nanoscale? Available online: https: //www.nano.gov/nanotech-101/special (accessed on 14 July 2020).

7. Brydson, R.M.; Hammond, C. Generic Methodologies for Nanotechnology: Classification and Fabrication. In Nanoscale Science and Technology; John Wiley \& Sons, Ltd.: Hoboken, NJ, USA, 2005; pp. 1-55, ISBN 9780470850862.

8. Vance, M.E.; Kuiken, T.; Vejerano, E.P.; McGinnis, S.P.; Hochella, M.F.; Hull, D.R. Nanotechnology in the real world: Redeveloping the nanomaterial consumer products inventory. Beilstein J. Nanotechnol. 2015, 6, 1769-1780. [CrossRef] [PubMed]

9. Nanowerk Database Nanoparticle Database-Single-Element Nanoparticles. Available online: https: //www.nanowerk.com/nanoparticle_database.php (accessed on 20 April 2020).

10. Parisi, C.; Vigani, M.; Rodríguez-Cerezo, E. Agricultural nanotechnologies: What are the current possibilities? Nano Today 2015, 10, 124-127. [CrossRef]

11. Sim, W.; Barnard, R.T.; Blaskovich, M.A.T.; Ziora, Z.M. Antimicrobial silver in medicinal and consumer applications: A patent review of the past decade (2007-2017). Antibiotics 2018, 7, 93. [CrossRef] [PubMed]

12. Dilnawaz, F.; Acharya, S.; Sahoo, S.K. Recent trends of nanomedicinal approaches in clinics. Int. J. Pharm. 2018, 538, 263-278. [CrossRef] [PubMed] 
13. Pelaz, B.; Alexiou, C.; Alvarez-Puebla, R.A.; Alves, F.; Andrews, A.M.; Ashraf, S.; Balogh, L.P.; Ballerini, L.; Bestetti, A.; Brendel, C.; et al. Diverse Applications of Nanomedicine. ACS Nano 2017, 11, 2313-2381. [CrossRef]

14. Vazquez-Muñoz, R.; Borrego, B.; Juárez-Moreno, K.; García-García, M.; Mota Morales, J.D.; Bogdanchikova, N.; Huerta-Saquero, A. Toxicity of silver nanoparticles in biological systems: Does the complexity of biological systems matter? Toxicol. Lett. 2017, 276, 11-20. [CrossRef]

15. Romero-Urbina, D.G.; Lara, H.H.; Velázquez-Salazar, J.J.; Arellano-Jiménez, M.J.; Larios, E.; Srinivasan, A.; Lopez-Ribot, J.L.; Yacamán, M.J. Ultrastructural changes in methicillin-resistant Staphylococcus aureus induced by positively charged silver nanoparticles. Beilstein J. Nanotechnol. 2015, 6, 2396-2405. [CrossRef]

16. Baptista, P.V.; Mccusker, M.P.; Carvalho, A.; Ferreira, D.A. Nano-Strategies to Fight Multidrug Resistant Bacteria - "A Battle of the Titans". Front. Microbiol. 2018, 9, 1-26. [CrossRef]

17. Huh, A.J.; Kwon, Y.J. "Nanoantibiotics": A new paradigm for treating infectious diseases using nanomaterials in the antibiotics resistant era. J. Control. Release 2011, 156, 128-145. [CrossRef]

18. Teixeira, M.C.; Carbone, C.; Sousa, M.C.; Espina, M.; Garcia, M.L.; Sanchez-Lopez, E.; Souto, E.B. Nanomedicines for the delivery of antimicrobial peptides (Amps). Nanomaterials 2020, 10, 560. [CrossRef] [PubMed]

19. Kim, D.; Kim, J.; Park, Y.I.; Lee, N.; Hyeon, T. Recent Development of Inorganic Nanoparticles for Biomedical Imaging. ACS Cent. Sci. 2018, 4, 324-336. [CrossRef] [PubMed]

20. Zottel, A.; Videtič Paska, A.; Jovčevska, I. Nanotechnology Meets Oncology: Nanomaterials in Brain Cancer Research, Diagnosis and Therapy. Materials (Basel). 2019, 12, 1588. [CrossRef] [PubMed]

21. Syafiuddin, A.; Salim, M.R.; Beng Hong Kueh, A.; Hadibarata, T.; Nur, H. A Review of Silver Nanoparticles: Research Trends, Global Consumption, Synthesis, Properties, and Future Challenges. J. Chin. Chem. Soc. 2017, 64, 732-756. [CrossRef]

22. Elechiguerra, J.L.; Burt, J.L.; Morones, J.R.; Camacho-Bragado, A.; Gao, X.; Lara, H.H.; Yacaman, M.J. Interaction of silver nanoparticles with HIV-1. J. Nanobiotechnol. 2005, 3, 1-10. [CrossRef] [PubMed]

23. Rogers, J.V.; Parkinson, C.V.; Choi, Y.W.; Speshock, J.L.; Hussain, S.M. A preliminary assessment of silver nanoparticle inhibition of monkeypox virus plaque formation. Nanoscale Res. Lett. 2008, 3, 129-133. [CrossRef]

24. Lu, L.; Sun, R.W.Y.; Chen, R.; Hui, C.K.; Ho, C.M.; Luk, J.M.; Lau, G.K.K.; Che, C.M. Silver nanoparticles inhibit hepatitis B virus replication. Antivir. Ther. 2008, 13, 252-262.

25. Speshock, J.L.; Murdock, R.C.; Braydich-Stolle, L.K.; Schrand, A.M.; Hussain, S.M. Interaction of silver nanoparticles with Tacaribe virus. J. Nanobiotechnol. 2010, 8, 1-9. [CrossRef]

26. Borrego, B.; Lorenzo, G.; Mota-Morales, J.D.; Almanza-Reyes, H.; Mateos, F.; López-Gil, E.; de la Losa, N.; Burmistrov, V.A.; Pestryakov, A.N.; Brun, A.; et al. Potential application of silver nanoparticles to control the infectivity of Rift Valley fever virus in vitro and in vivo. Nanomed. Nanotechnol. Biol. Med. 2016, 12, 1185-1192. [CrossRef]

27. Xiang, D.; Zheng, C.; Zheng, Y.; Li, X.; Yin, J.; O' Conner, M.; Marappan, M.; Miao, Y.; Xiang, B.; Duan, W.; et al. Inhibition of A/Human/Hubei/3/2005 (H3N2) influenza virus infection by silver nanoparticles in vitro and in vivo. Int. J. Nanomed. 2013, 8, 4103. [CrossRef]

28. Mori, Y.; Ono, T.; Miyahira, Y.; Nguyen, V.Q.; Matsui, T.; Ishihara, M. Antiviral activity of silver nanoparticle/chitosan composites against H1N1 influenza A virus. Nanoscale Res. Lett. 2013, 8, 93. [CrossRef] [PubMed]

29. Chen, Y.-N.; Hsueh, Y.-H.; Hsieh, C.-T.; Tzou, D.-Y.; Chang, P.-L. Antiviral Activity of Graphene-Silver Nanocomposites against Non-Enveloped and Enveloped Viruses. Int. J. Environ. Res. Public Health 2016, 13, 430. [CrossRef] [PubMed]

30. Cui, H.; Jiang, J.; Gu, W.; Sun, C.; Wu, D.; Yang, T.; Yang, G. Photocatalytic Inactivation Efficiency of Anatase Nano-TiO2 Sol on the H9N2 Avian Influenza Virus. Photochem. Photobiol. 2010, 86, 1135-1139. [CrossRef] [PubMed]

31. Ji, H.; Yang, Z.; Jiang, W.; Geng, C.; Gong, M.; Xiao, H.; Wang, Z.; Cheng, L. Antiviral activity of nano carbon fullerene lipidosome against influenza virus in vitro. J. Huazhong Univ. Sci. Technol. 2008, 28, 243-246. [CrossRef] [PubMed] 
32. Lauster, D.; Glanz, M.; Bardua, M.; Ludwig, K.; Hellmund, M.; Hoffmann, U.; Hamann, A.; Böttcher, C.; Haag, R.; Hackenberger, C.P.R.; et al. Multivalent Peptide-Nanoparticle Conjugates for Influenza-Virus Inhibition. Angew. Chem. Int. Ed. 2017, 56, 5931-5936. [CrossRef] [PubMed]

33. Surnar, B.; Kamran, M.Z.; Shah, A.S.; Basu, U.; Kolishetti, N.; Deo, S.; Jayaweera, D.T.; Daunert, S.; Dhar, S.; Macdonald, J.T. Orally Administrable Therapeutic Synthetic Nanoparticle for Zika Virus. ACS nano 2019, 13, 11034-11048. [CrossRef]

34. Chan, W.C.W. Nano Research for COVID-19. ACS Nano 2020. [CrossRef]

35. Morris, D.; Ansar, M.; Speshock, J.; Ivanciuc, T.; Qu, Y.; Casola, A.; Garofalo, R. Antiviral and Immunomodulatory Activity of Silver Nanoparticles in Experimental RSV Infection. Viruses 2019, 11, 732. [CrossRef]

36. Kovarova, M.; Council, O.D.; Date, A.A.; Long, J.M.; Nochii, T.; Belshan, M.; Shibata, A.; Vincent, H.; Baker, C.E.; Thayer, W.O.; et al. Nanoformulations of Rilpivirine for Topical Pericoital and Systemic Coitus-Independent Administration Efficiently Prevent HIV Transmission. PLoS Pathog. 2015, 11, e1005075. [CrossRef]

37. Donovan, B.W.; Reuter, J.D.; Cao, Z.; Myc, A.; Johnson, K.J.; Baker, J.R. Prevention of murine influenza A virus pneumonitis by surfactant nano-emulsions. Antivir. Chem. Chemother. 2000, 11, 41-49. [CrossRef] [PubMed]

38. Cagno, V.; Andreozzi, P.; D’Alicarnasso, M.; Silva, P.J.; Mueller, M.; Galloux, M.; Le Goffic, R.; Jones, S.T.; Vallino, M.; Hodek, J.; et al. Broad-spectrum non-toxic antiviral nanoparticles with a virucidal inhibition mechanism. Nat. Mater. 2018, 17, 195-203. [CrossRef] [PubMed]

39. Bogdanchikova, N.; Muñoz, R.V.; Saquero, A.H.; Jasso, A.P.; Uzcanga, G.A.; Díaz, P.L.P.; Pestryakov, A.; Burmistrov, V.; Martynyuk, O.; Gómez, R.L.V.; et al. Silver nanoparticles composition for treatment of distemper in dogs. Int. J. Nanotechnol. 2016, 13, 227. [CrossRef]

40. Nazaktabar, A.; Lashkenari, M.S.; Araghi, A.; Ghorbani, M.; Golshahi, H. In vivo evaluation of toxicity and antiviral activity of polyrhodanine nanoparticles by using the chicken embryo model. Int. J. Biol. Macromol. 2017, 103, 379-384. [CrossRef] [PubMed]

41. Ufaz, S.; Balter, A.; Tzror, C.; Einbender, S.; Koshet, O.; Shainsky-Roitman, J.; Yaari, Z.; Schroeder, A. Anti-viral RNAi nanoparticles protect shrimp against white spot disease. Mol. Syst. Des. Eng. 2018, 3, 38-48. [CrossRef]

42. Kim, S.S.; Peer, D.; Kumar, P.; Subramanya, S.; Wu, H.; Asthana, D.; Habiro, K.; Yang, Y.G.; Manjunath, N.; Shimaoka, M.; et al. RNAi-mediated CCR5 silencing by LFA-1-targeted nanoparticles prevents HIV infection in BLT mice. Mol. Ther. 2010, 18, 370-376. [CrossRef] [PubMed]

43. Tatham, L.M.; Savage, A.C.; Dwyer, A.; Siccardi, M.; Scott, T.; Vourvahis, M.; Clark, A.; Rannard, S.P.; Owen, A. Towards a Maraviroc long-acting injectable nanoformulation. Eur. J. Pharm. Biopharm. 2019, 138, 92-98. [CrossRef]

44. Herzog, C.; Hartmann, K.; Künzi, V.; Kürsteiner, O.; Mischler, R.; Lazar, H.; Glück, R. Eleven years of Inflexal ${ }^{\circledR} \mathrm{V}-\mathrm{A}$ virosomal adjuvanted influenza vaccine. Vaccine 2009, 27, 4381-4387. [CrossRef]

45. Alconcel, S.N.S.; Baas, A.S.; Maynard, H.D. FDA-approved poly(ethylene glycol)-protein conjugate drugs. Polym. Chem. 2011, 2, 1442-1448. [CrossRef]

46. Donalisio, M.; Leone, F.; Civra, A.; Spagnolo, R.; Ozer, O.; Lembo, D.; Cavalli, R. Acyclovir-Loaded Chitosan Nanospheres from Nano-Emulsion Templating for the Topical Treatment of Herpesviruses Infections. Pharmaceutics 2018, 10, 46. [CrossRef]

47. Seto, W.K.; Yuen, M.F. New pharmacological approaches to a functional cure of hepatitis B. Clin. Liver Dis. 2016, 8, 83-88. [CrossRef] [PubMed]

48. Lara, H.H.; Ayala-Nuñez, N.V.; Ixtepan-Turrent, L.; Rodriguez-Padilla, C. Mode of antiviral action of silver nanoparticles against HIV-1. J. Nanobiotechnol. 2010, 8, 1-10. [CrossRef] [PubMed]

49. Cojocaru, F.D.; Botezat, D.; Gardikiotis, I.; Uritu, C.M.; Dodi, G.; Trandafir, L.; Rezus, C.; Rezus, E.; Tamba, B.I.; Mihai, C.T. Nanomaterials designed for antiviral drug delivery transport across biological barriers. Pharmaceutics 2020, 12, 171. [CrossRef] [PubMed]

50. Pulit-Prociak, J.; Banach, M. Silver nanoparticles-A material of the future...? Open Chem. 2016, 14, 76-91. [CrossRef]

51. Ali, A.; Ahmed, S. A review on chitosan and its nanocomposites in drug delivery. Int. J. Biol. Macromol. 2018, 109, 273-286. [CrossRef] [PubMed] 
52. Lembo, D.; Donalisio, M.; Civra, A.; Argenziano, M.; Cavalli, R. Nanomedicine formulations for the delivery of antiviral drugs: A promising solution for the treatment of viral infections. Expert Opin. Drug Deliv. 2018, 15, 93-114. [CrossRef]

53. Singh, L.; Kruger, H.G.; Maguire, G.E.M.; Govender, T.; Parboosing, R. The role of nanotechnology in the treatment of viral infections. Ther. Adv. Infect. Dis. 2017, 4, 105-131. [CrossRef]

54. Ventola, C.L. Progress in nanomedicine: Approved and investigational nanodrugs. P T 2017, 42, 742-755.

55. Emam, H.E.; Manian, A.P.; Široká, B.; Duelli, H.; Redl, B.; Pipal, A.; Bechtold, T. Treatments to impart antimicrobial activity to clothing and household cellulosic-textiles-Why "nano"-silver? J. Clean. Prod. 2013, 39, 17-23. [CrossRef]

56. Massella, D.; Giraud, S.; Guan, J.; Ferri, A.; Salaün, F. Textiles for health: A review of textile fabrics treated with chitosan microcapsules. Environ. Chem. Lett. 2019, 17, 1787-1800. [CrossRef]

57. Yetisen, A.K.; Qu, H.; Manbachi, A.; Butt, H.; Dokmeci, M.R.; Hinestroza, J.P.; Skorobogatiy, M.; Khademhosseini, A.; Yun, S.H. Nanotechnology in Textiles. ACS Nano 2016, 10, 3042-3068. [CrossRef] [PubMed]

58. Brabazon, D.; Pellicer, E.; Zivic, F.; Sort, J.; Baró, M.D.; Grujovic, N.; Choy, K.L. Commercialization of Nanotechnologies-A Case Study Approach; Brabazon, D., Pellicer, E., Zivic, F., Sort, J., Dolors Baró, M., Grujovic, N., Choy, K.-L., Eds.; Springer International Publishing: Cham, Switzerland, 2017; ISBN 9783319569796.

59. Suryaprabha, T.; Sethuraman, M.G. Fabrication of copper-based superhydrophobic self-cleaning antibacterial coating over cotton fabric. Cellulose 2017, 24, 395-407. [CrossRef]

60. Mao, N. Textile Materials for Protective Textiles. In High Performance Technical Textiles; John Wiley \& Sons, Ltd.: Chichester, UK, 2019; pp. 107-157.

61. Libertino, S.; Plutino, M.R.; Rosace, G. Design and development of wearable sensing nanomaterials for smart textiles. In Proceedings of the AIP Conference Proceedings; AIP Publishing LLC: Melville, NY, USA, 2018; Volume 1990, p. 020016.

62. Jayathilaka, W.A.D.M.; Qi, K.; Qin, Y.; Chinnappan, A.; Serrano-García, W.; Baskar, C.; Wang, H.; He, J.; Cui, S.; Thomas, S.W.; et al. Significance of Nanomaterials in Wearables: A Review on Wearable Actuators and Sensors. Adv. Mater. 2019, 31. [CrossRef] [PubMed]

63. Hebalkar, N.Y.; Acharya, S.; Rao, T.N. Preparation of bi-functional silica particles for antibacterial and self cleaning surfaces. J. Colloid Interface Sci. 2011, 364, 24-30. [CrossRef] [PubMed]

64. Hasan, J.; Crawford, R.J.; Ivanova, E.P. Antibacterial surfaces: The quest for a new generation of biomaterials. Trends Biotechnol. 2013, 31, 295-304. [CrossRef] [PubMed]

65. Zhao, L.; Chu, P.K.; Zhang, Y.; Wu, Z. Antibacterial coatings on titanium implants. J. Biomed. Mater. Res. Part B Appl. Biomater. 2009, 91B, 470-480. [CrossRef] [PubMed]

66. Elbourne, A.; Crawford, R.J.; Ivanova, E.P. Nano-structured antimicrobial surfaces: From nature to synthetic analogues. J. Colloid Interface Sci. 2017, 508, 603-616. [CrossRef]

67. Rai, P.K.; Usmani, Z.; Thakur, V.K.; Gupta, V.K.; Mishra, Y.K. Tackling COVID-19 pandemic through nanocoatings: Confront and exactitude. Curr. Res. Green Sustain. Chem. 2020, 3, 100011. [CrossRef]

68. Ku, T.S.N.; Walraven, C.J.; Lee, S.A. Candida auris: Disinfectants and Implications for Infection Control. Front. Microbiol. 2018, 9. [CrossRef]

69. Culver, A.; Geiger, C.; Simon, D. Safer Products and Practices for Disinfecting and Sanitizing Surfaces; SF Environment: San Francisco, CA, USA, 2014.

70. Vaze, N.; Pyrgiotakis, G.; McDevitt, J.; Mena, L.; Melo, A.; Bedugnis, A.; Kobzik, L.; Eleftheriadou, M.; Demokritou, P. Inactivation of common hospital acquired pathogens on surfaces and in air utilizing engineered water nanostructures (EWNS) based nano-sanitizers. Nanomed. Nanotechnol. Biol. Med. 2019, 18, 234-242. [CrossRef]

71. Joe, Y.H.; Park, D.H.; Hwang, J. Evaluation of Ag nanoparticle coated air filter against aerosolized virus: Anti-viral efficiency with dust loading. J. Hazard. Mater. 2016, 301, 547-553. [CrossRef] [PubMed]

72. Martínez-Montelongo, J.H.; Medina-Ramírez, I.E.; Romo-Lozano, Y.; Zapien, J.A. Development of a sustainable photocatalytic process for air purification. Chemosphere 2020. [CrossRef] [PubMed]

73. Pedroza-Herrera, G.; Medina-Ramírez, I.E.; Lozano-Álvarez, J.A.; Rodil, S.E. Evaluation of the Photocatalytic Activity of Copper Doped TiO 2 nanoparticles for the Purification and/or Disinfection of Industrial Effluents. Catal. Today 2018. [CrossRef] 
74. Mishra, M.; Kumar, H.; Tripathi, K. Diabetic Delayed Wound Healing and the Role of Silver. Dig. J. Nano 2008, 3, 49-54. [CrossRef]

75. Zivic, F.; Grujovic, N.; Mitrovic, S.; Ahad, I.U.; Brabazon, D. Characteristics and applications of silver nanoparticles. In Commercialization of Nanotechnologies-A Case Study Approach; Springer International Publishing: Berlin/Heidelberg, Germany, 2017; pp. 227-273, ISBN 9783319569796.

76. Hameed, S.; Xie, L.; Ying, Y. Conventional and emerging detection techniques for pathogenic bacteria in food science: A review. Trends Food Sci. Technol. 2018, 81, 61-73. [CrossRef]

77. Zhong, Y.; Godwin, P.; Jin, Y.; Xiao, H. Biodegradable polymers and green-based antimicrobial packaging materials: A mini-review. Adv. Ind. Eng. Polym. Res. 2020, 3, 27-35. [CrossRef]

78. Xu, K.; Cai, H.; Shen, Y.; Ni, Q.; Chen, Y.; Hu, S.; Li, J.; Wang, H.; Yu, L.; Huang, H.; et al. Management of corona virus disease-19 (COVID-19): The Zhejiang experience. Zhejiang Da Xue Xue Bao. Yi Xue Ban 2020, 49. [CrossRef]

79. Luo, X.; Xia, H.; Yang, W.; Wang, B.; Guo, T.; Xiong, J.; Jiang, Z.; Liu, Y.; Yan, X.; Zhou, W.; et al. Characteristics of patients with COVID-19 during epidemic ongoing outbreak in Wuhan, China. MedRxiv 2020. [CrossRef]

80. Rawson, T.M.; Moore, L.S.P.; Zhu, N.; Ranganathan, N.; Skolimowska, K.; Gilchrist, M.; Satta, G.; Cooke, G.; Holmes, A. Bacterial and fungal co-infection in individuals with coronavirus: A rapid review to support COVID-19 antimicrobial prescribing. Clin. Infect. Dis. 2020. [CrossRef]

81. Centers for Disease Control and Prevention. Antibiotic Resistance Threats in the United States; U.S. Centers for Disease Control and Prevention: Atlanta, GA, USA, 2019.

82. Vazquez-Muñoz, R.; Arellano-Jimenez, M.J.; Lopez, F.D.; Lopez-Ribot, J.L. Protocol optimization for a fast, simple and economical chemical reduction synthesis of antimicrobial silver nanoparticles in non-specialized facilities. BMC Res. Notes 2019, 12, 773. [CrossRef]

83. Vega-Jiménez, A.L.; Almaguer-Flores, A.; Flores-Castaneda, M.; Camps, E.; Uribe-Ramirez, M.; Aztatzi-Aguilar, O.G.; De Vizcaya-Ruiz, A. Bismuth subsalicylate nanoparticles with anaerobic antibacterial activity for dental applications. Nanotechnology 2017, 28, 435101. [CrossRef] [PubMed]

84. Gaafar, M.R.; Mady, R.F.; Diab, R.G.; Shalaby, T.I. Chitosan and silver nanoparticles: Promising anti-toxoplasma agents. Exp. Parasitol. 2014, 143, 30-38. [CrossRef] [PubMed]

85. Kurvet, I.; Juganson, K.; Vija, H.; Sihtmäe, M.; Blinova, I.; Syvertsen-Wiig, G.; Kahru, A. Toxicity of nine (doped) rare earth metal oxides and respective individual metals to aquatic microorganisms Vibrio fischeri and Tetrahymena thermophila. Materials 2017, 10, 754. [CrossRef] [PubMed]

86. Lara, H.H.; Guisbiers, G.; Mendoza, J.; Mimun, L.C.; Vincent, B.A.; Lopez-Ribot, J.L.; Nash, K.L. Synergistic antifungal effect of chitosan-stabilized selenium nanoparticles synthesized by pulsed laser ablation in liquids against Candida albicans biofilms. Int. J. Nanomed. 2018, 13, 2697-2708. [CrossRef]

87. Montes, M.; Pierce, C.G.; Lopez-Ribot, J.L.; Bhalla, A.S.; Guo, R. Properties of silver and copper nanoparticle containing aqueous suspensions and evaluation of their in vitro activity against candida albicans and staphylococcus aureus biofilms. J. Nano Res. 2016, 37, 109-121. [CrossRef]

88. Lara, H.H.; Ixtepan-Turrent, L.; Jose Yacaman, M.; Lopez-Ribot, J. Inhibition of Candida auris Biofilm Formation on Medical and Environmental Surfaces by Silver Nanoparticles. ACS Appl. Mater. Interfaces 2020. [CrossRef]

89. Vazquez-Muñoz, R.; Avalos-Borja, M.; Castro-Longoria, E. Ultrastructural Analysis of Candida albicans When Exposed to Silver Nanoparticles. PLoS ONE 2014, 9, e108876. [CrossRef]

90. Frei, A.; Zuegg, J.; Elliott, A.G.; Baker, M.; Braese, S.; Brown, C.; Chen, F.; Dowson, C.G.; Dujardin, G.; Jung, N.; et al. Metal complexes as a promising source for new antibiotics. Chem. Sci. 2020, 11, 2627-2639. [CrossRef]

91. Vazquez-Muñoz, R.; Meza-Villezcas, A.; Fournier, P.G.J.; Soria-Castro, E.; Juarez-Moreno, K.; Gallego-Hernández, A.L.; Bogdanchikova, N.; Vazquez-Duhalt, R.; Huerta-Saquero, A. Enhancement of antibiotics antimicrobial activity due to the silver nanoparticles impact on the cell membrane. PLoS ONE 2019, 14, e0224904. [CrossRef]

92. Vazquez-Munoz, R.; Lopez, F.D.; Lopez-Ribot, J.L. Silver nanoantibiotics display strong antifungal activity against the emergent multidrug-resistant yeast Candida auris under both planktonic and biofilm growing conditions. Front. Microbiol. 2020, 11, 1673. [CrossRef]

93. Möhler, J.S.; Sim, W.; Blaskovich, M.A.T.; Cooper, M.A.; Ziora, Z.M. Silver bullets: A new lustre on an old antimicrobial agent. Biotechnol. Adv. 2018, 36, 1391-1411. [CrossRef] [PubMed] 
94. Khandelwal, P.; Singh, D.K.; Poddar, P. Advances in the Experimental and Theoretical Understandings of Antibiotic Conjugated Gold Nanoparticles for Antibacterial Applications. ChemistrySelect 2019, 4, 6719-6738. [CrossRef]

95. Murakami, N.; Wakabayashi, N.; Matsushima, R.; Kishida, A.; Igarashi, Y. Effect of high-pressure polymerization on mechanical properties of PMMA denture base resin. J. Mech. Behav. Biomed. Mater. 2013, 20, 98-104. [CrossRef] [PubMed]

96. Edis, Z.; Haj Bloukh, S.; Ashames, A.; Ibrahim, M. Copper-Based Nanoparticles, Their Chemistry and Antibacterial Properties: A Review. In Chemistry for a Clean and Healthy Planet; Springer International Publishing: Berlin/Heidelberg, Germany, 2019; pp. 401-428.

97. Gao, W.; Chen, Y.; Zhang, Y.; Zhang, Q.; Zhang, L. Nanoparticle-based local antimicrobial drug delivery. Adv. Drug Deliv. Rev. 2018, 127, 46-57. [CrossRef] [PubMed]

98. Makowski, M.; Silva, Í.C.; Pais do Amaral, C.; Gonçalves, S.; Santos, N.C. Advances in Lipid and Metal Nanoparticles for Antimicrobial Peptide Delivery. Pharmaceutics 2019, 11, 588. [CrossRef]

99. Bui, V.; Park, D.; Lee, Y.-C. Chitosan Combined with ZnO, TiO2 and Ag Nanoparticles for Antimicrobial Wound Healing Applications: A Mini Review of the Research Trends. Polymers 2017, 9, 21. [CrossRef]

100. Nikam, A.V.; Prasad, B.L.V.; Kulkarni, A.A. Wet chemical synthesis of metal oxide nanoparticles: A review. CrystEngComm 2018, 20, 5091-5107. [CrossRef]

101. Vazquez-Munoz, R.; Arellano-Jimenez, M.J.; Lopez-Ribot, J.L. Fast, facile synthesis method for BAL-mediated PVP-bismuth nanoparticles. MethodsX 2020, 7, 100894. [CrossRef]

(C) 2020 by the authors. Licensee MDPI, Basel, Switzerland. This article is an open access article distributed under the terms and conditions of the Creative Commons Attribution (CC BY) license (http://creativecommons.org/licenses/by/4.0/). 